\title{
Expression profiling analysis of hypoxic pulmonary disease
}

L. Zhou, L.M. Wang, H.M. Song, Y.Q. Shen, W.J. Xu, J.H. Xu, Y. Liu, W.W. Yan and J.F. Jiang

Department of Cardiology, Tongji Hospital, Tongji University School of Medicine, Shanghai, China

Corresponding author: J. Jiang

E-mail: jinfajiangjiang@hotmail.com

Genet. Mol. Res. 12 (4): 4162-4170 (2013)

Received September 18, 2012

Accepted January 16, 2013

Published October 7, 2013

DOI http://dx.doi.org/10.4238/2013.October.7.2

\begin{abstract}
Exposure of humans to low levels of environmental oxygen results in alveolar hypoxia and normally causes chronic pulmonary hypertension and morphological alterations of precapillary pulmonary vessels. In this study, the microarray dataset GSE11341 was used to identify potential differentially expressed genes related with human lung microvascular endothelial cell hypoxia. In addition, gene ontology term enrichment analysis was performed to explore their underlying functions. In addition, we also investigated the small molecules by comparing with the Connectivity Map. We found that hypoxia samples of 3,24, and $48 \mathrm{~h}$ relative to $0 \mathrm{~h}$ displayed 22, 21, and 29 differentially expressed genes, respectively. Among them, six genes (ADM, HMOX1, VEGFA, EGLN3, APOLD1, and ANGPTL4) were closely related to pulmonary microvascular endothelial cell hypoxia response. Three drugs (pindolol, sulfapyridine, and ciclopirox) were selected as candidates to treat hypoxia-related pulmonary diseases. In conclusion, our results provide some underlying drug targets for treatment of hypoxic pulmonary patients.
\end{abstract}

Key words: Pulmonary hypoxia-related diseases; Similar drugs; Differentially expressed genes; CMAP 


\section{INTRODUCTION}

Pulmonary hypoxia is a common consequence of chronic lung diseases and leads to the development of pulmonary hypertension with smooth muscle cell proliferation and matrix deposition in the wall of the pulmonary arterioles (Minamino et al., 2001), Pulmonary hypertension is characterized by shortness of breath, dizziness, fainting, and other symptoms, all of which are exacerbated by exertion (Beghetti et al., 2011). The ability of pulmonary epithelial cells to cope with low oxygen tensions is crucial to maintain the structural and functional integrity of the pulmonary epithelium (Clerici and Planès, 2009).

In order to prevent oxygen depletion, cells attempt to maintain ATP synthesis by upregulation of glycolytic enzymes such as glucose transporters (GLUT), hexokinases (HK), and phosphofructokinase (PFK) (Tuder et al., 2012). Pulmonary epithelial cells also can induce vascular endothelial growth factor (VEGF) by hypoxia-inducible factor 1(HIF-1) during hypoxia (Shimoda and Semenza, 2011). The increase in VEGF stimulates angiogenesis, which increases oxygen delivery. In addition to increasing oxygen supply, hypoxia diminishes oxygen demand by reversibly decreasing cellular ATP consumption pathways, such as $\mathrm{Na}+\mathrm{K}+-$ ATPase activity (Zhou et al., 2008).

However, the molecular mechanism is still not fully understood. DNA microarray technology is a powerful tool for rapid, comprehensive, and quantitative analysis of gene expression profiles of normal and disease states (Chen et al., 2001). This technology has been successfully applied to identify potential target genes for pulmonary hypoxia (Truog et al., 2008; Zhou et al., 2011). In this study, we aimed to apply the same approach to compare gene responses to hypoxia for different hypoxia exposure time in human pulmonary microvascular endothelial cells. The biological processes were also analyzed to interpret potential molecular mechanisms. In pulmonary hypertension, lifestyle changes, digoxin, diuretics, oral anticoagulants, and oxygen therapy are considered as conventional treatment strategies, but these have never been proven to be beneficial in a randomized, prospective manner (Barst et al., 2004). Therefore, we also aimed to explore some potential therapeutic drug candidates by comparing with the Connectivity Map (CMAP) in this study.

\section{MATERIAL AND METHODS}

\section{Expression data preprocessing on pulmonary hypoxic disease}

Expression profiling of GSE11341 (Su et al., 2011) was obtained from the public functional genomics data repository Gene Expression Omnibus (GEO, http://www.ncbi.nlm. nih.gov/geo/), which is based on the Affymetrix GPL571 platform data (Affymetrix Human Genome U133A 2.0 Array). Eight hypoxia $\left(1 \% \mathrm{O}_{2}\right.$, two for $3 \mathrm{~h}$, three for $24 \mathrm{~h}$, and three 48 h) and three normoxia $\left(21 \% \mathrm{O}_{2}, 0 \mathrm{~h}\right)$ chips were applied to identify differentially expressed genes. The original CEL files and the platform probe annotation information file were also downloaded for the next step of bioinformatics analysis. First, the raw data were transformed into identifiable expression profiling formats, and then the missing part of the data was filled (Troyanskaya et al., 2001). Finally, the missing data were normalized using the average of standardized methods (Fujita et al., 2006). 


\section{Differential gene expression analysis}

The different chips were normalized using the robust multichip average (RMA) algorithm available in the R affy package (v.2.13.0) and the linear model was then constructed. Significance of differential expression between the different treatments was tested by R package limma (Gentleman, 2005) and adjusted for multiple comparisons using the false discovery rate (FDR) of Benjamini and Hochberg (Benjamini and Hochberg, 1995). Only the genes with FDR $<0.05$ and $|\operatorname{logFC}|>0.05$ were selected as differentially expressed genes.

\section{Gene Ontology (GO) enrichment of differentially expressed genes}

The database for annotation, visualization and integrated discovery (DAVID) (Huang et al., 2009) was used to identify over-represented GO terms in biological process. $\mathrm{P}$ value $<0.05$ and FDR $<0.05$ were set as the threshold for this analysis using the hypergeometric distribution.

\section{Researching similar drugs in CMAP}

CMAP is a collection of genome-wide transcriptional expression data from cultured human cells treated with bioactive small molecules (Lamb et al., 2006). It includes 6120 genome-wide expression profiles representing 5812 individual treatment instances with 1210 bioactive small molecules. By comparing the expression pattern similarity of differentially expressed genes and the genes perturbed in CMAP instances, a list of small bio-active molecules related to the input genes will be identified.

\section{RESULTS}

\section{Analysis of differentially expressed genes}

Due to various reasons, such as background and the probe design, the original microarray data showed a great difference between the microarray data, so the data had to be normalized. After data preprocessing, gene expression profile data with higher normalization (Figure 1) was used for differentially expressed gene analysis. The differentially expressed genes were analyzed using the R language limma package and BH method was used for multiple test correction. Hypoxia samples of 3,24 , and $48 \mathrm{~h}$ relative to $0 \mathrm{~h}$ displayed respectively 22,21 and 29 differentially expressed genes with the $\mathrm{P}$ value $<0.05$ and $|\log \mathrm{FC}|>1$. All data are shown in Table 1.

Venn diagrams were used to display the differentially expressed genes that overlapped between the 0 h-3 h, 0 h-24 h, and 0 h- 48 h comparisons (Figure 2). We found there were 6 common differentially expressed genes between $0 v s 3 \mathrm{~h}$ group and $0 v s 24 \mathrm{~h}$ group, 21 between $0 v s 3 \mathrm{~h}$ group and $0 v s 48 \mathrm{~h}$ group, and 8 between $0 v s 48 \mathrm{~h}$ group and $0 v s 24 \mathrm{~h}$ group. Importantly, 3 differentially expressed genes overlapped in the three groups, including 201170_s_at (BHLHE40), 202912_at (ADM), and 221009_s_at (ANGPTL4). 


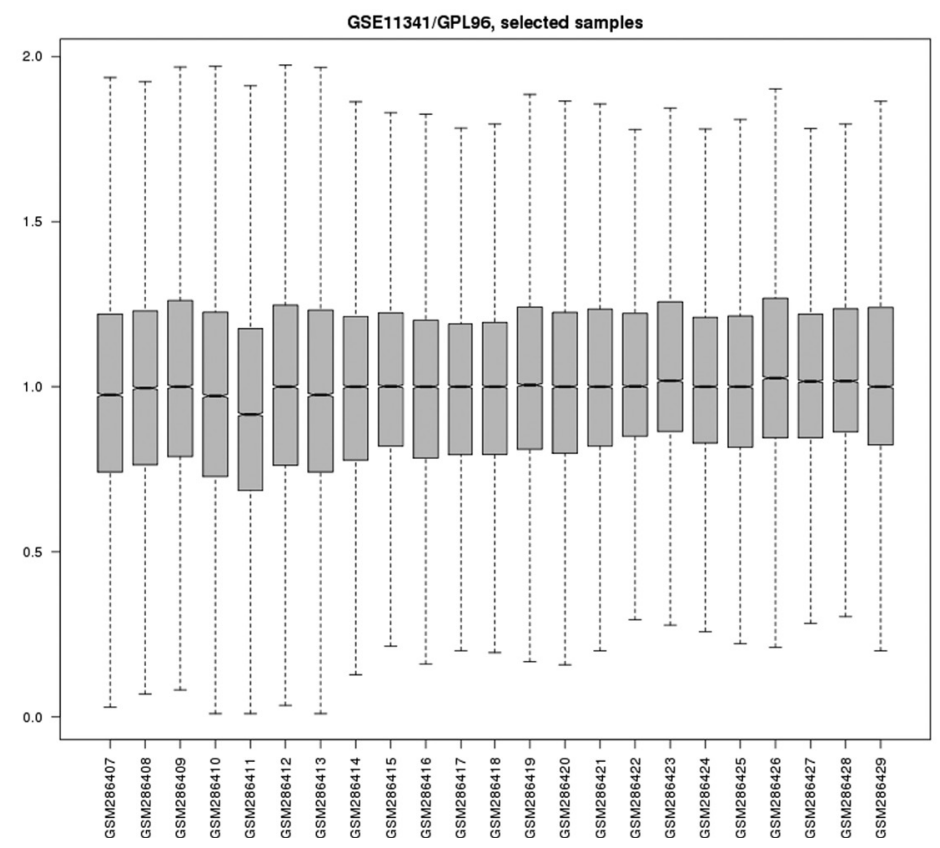

Figure 1. Box plots distribution. Horizontal line in the box $=$ median of the statistic. Standardized approach in a line indicates the high degree of the data.

Table 1. Differentially expressed genes meeting the threshold.

\begin{tabular}{|c|c|c|c|c|c|c|c|c|}
\hline \multicolumn{3}{|c|}{$0 v s 3 \mathrm{~h}$} & \multicolumn{3}{|c|}{$0 v s 24 \mathrm{~h}$} & \multicolumn{3}{|c|}{$0 v s 48 \mathrm{~h}$} \\
\hline Gene symbol & P value & $\log \mathrm{FC}$ & Gene symbol & $P$ value & $\log \mathrm{FC}$ & Gene symbol & P value & $\operatorname{logFC}$ \\
\hline TRHDE & $2.73 \mathrm{E}-05$ & -1.8866 & NFX1 & 0.000199 & -2.62287 & KLHL1 & $3.82 \mathrm{E}-05$ & -1.68397 \\
\hline HMOX1 & $8.73 \mathrm{E}-06$ & -1.6121 & EPCAM & 0.00142 & -2.30155 & HMOX1 & $7.74 \mathrm{E}-07$ & -1.66462 \\
\hline GADD45B & $2.44 \mathrm{E}-05$ & 1.0673 & C8orf71 & 0.001254 & -2.24564 & METTL7A & $2.31 \mathrm{E}-06$ & -1.53712 \\
\hline CEBPD & $3.68 \mathrm{E}-05$ & 1.1732 & NRL & 0.001059 & -1.83964 & FRY & $3.63 \mathrm{E}-05$ & -1.48984 \\
\hline BNIP3L & $2.72 \mathrm{E}-05$ & 1.208 & BCAN & 0.001455 & -1.72776 & TMEM106C & $6.78 \mathrm{E}-05$ & -1.32209 \\
\hline BNIP3L & $7.82 \mathrm{E}-07$ & 1.2721 & FYB & 0.000774 & -1.53728 & KCTD12 & $6.75 \mathrm{E}-06$ & -1.21814 \\
\hline GADD45B & $1.71 \mathrm{E}-06$ & 1.3024 & BHLHE40 & 0.000021 & 1.288812 & BACH1 & $3.16 \mathrm{E}-05$ & 1.03098 \\
\hline TNFAIP3 & $6.69 \mathrm{E}-06$ & 1.3142 & BHLHE40 & $1.96 \mathrm{E}-06$ & 1.407635 & BNIP3L & $2.01 \mathrm{E}-06$ & 1.122516 \\
\hline SYNPO & $3.28 \mathrm{E}-05$ & 1.4197 & MGC2889 & 0.001185 & 1.445388 & TNFAIP3 & $9.42 \mathrm{E}-06$ & 1.123801 \\
\hline BHLHE40 & 3.83E-06 & 1.5151 & CGB8 & 0.00033 & 1.488764 & BHLHE40 & $5.47 \mathrm{E}-05$ & 1.183875 \\
\hline BACH1 & 3.84E-05 & 1.5257 & MTMR3 & 0.000153 & 1.595382 & GADD45B & 4.09E-06 & 1.187032 \\
\hline SLC2A1 & 9.84E-06 & 1.5322 & COL6A1 & 0.00079 & 1.680288 & ZZEF1 & $5.48 \mathrm{E}-05$ & 1.352717 \\
\hline TGFBI & $1.92 \mathrm{E}-05$ & 1.5422 & GRIA3 & 0.001476 & 1.881692 & ERO1L & $4.40 \mathrm{E}-05$ & 1.360875 \\
\hline SPAG4 & $1.77 \mathrm{E}-05$ & 1.5865 & ADM & 7.89E-05 & 1.895488 & GADD45B & $6.22 \mathrm{E}-06$ & 1.395541 \\
\hline ERO1L & 2.04E-05 & 1.598 & LOC100129656 & 0.001221 & 1.90726 & BHLHE40 & $5.53 \mathrm{E}-07$ & 1.423868 \\
\hline P4HA1 & $8.43 \mathrm{E}-06$ & 1.7103 & VEGFA & 0.000479 & 1.970068 & SYNPO & $3.28 \mathrm{E}-05$ & 1.424588 \\
\hline APOLD1 & $3.66 \mathrm{E}-06$ & 1.8397 & ANGPTL4 & $1.08 \mathrm{E}-05$ & 2.227879 & UGCG & $2.89 \mathrm{E}-05$ & 1.584409 \\
\hline ENO2 & $4.43 \mathrm{E}-05$ & 2.0385 & C15orf5 & 0.000529 & 2.309064 & P4HA1 & $3.64 \mathrm{E}-06$ & 1.612458 \\
\hline EGLN3 & $1.46 \mathrm{E}-05$ & 2.0612 & ELF5 & 0.001171 & 2.402506 & BACH1 & $5.64 \mathrm{E}-06$ & 1.638363 \\
\hline ADM & $1.00 \mathrm{E}-05$ & 2.132 & PCK1 & 0.001516 & 2.773377 & SLC2A1 & $1.64 \mathrm{E}-07$ & 1.772513 \\
\hline ANGPTL4 & $4.59 \mathrm{E}-06$ & 2.8591 & ENPEP & 0.000543 & 3.055239 & INHBA & 7.29E-06 & 1.840397 \\
\hline \multirow[t]{8}{*}{ NMU } & $2.18 \mathrm{E}-06$ & 3.5411 & & & & APOLD1 & $1.09 \mathrm{E}-06$ & 1.909467 \\
\hline & & & & & & TGFBI & $6.99 \mathrm{E}-07$ & 1.942184 \\
\hline & & & & & & EGLN3 & $1.07 \mathrm{E}-05$ & 2.06659 \\
\hline & & & & & & ADM & $3.20 \mathrm{E}-05$ & 2.088926 \\
\hline & & & & & & ENO2 & $1.37 \mathrm{E}-05$ & 2.215126 \\
\hline & & & & & & NMU & $6.81 \mathrm{E}-05$ & 2.870841 \\
\hline & & & & & & ANGPTL4 & $5.60 \mathrm{E}-07$ & 2.907398 \\
\hline & & & & & & VEGFA & $1.46 \mathrm{E}-05$ & 3.243183 \\
\hline
\end{tabular}




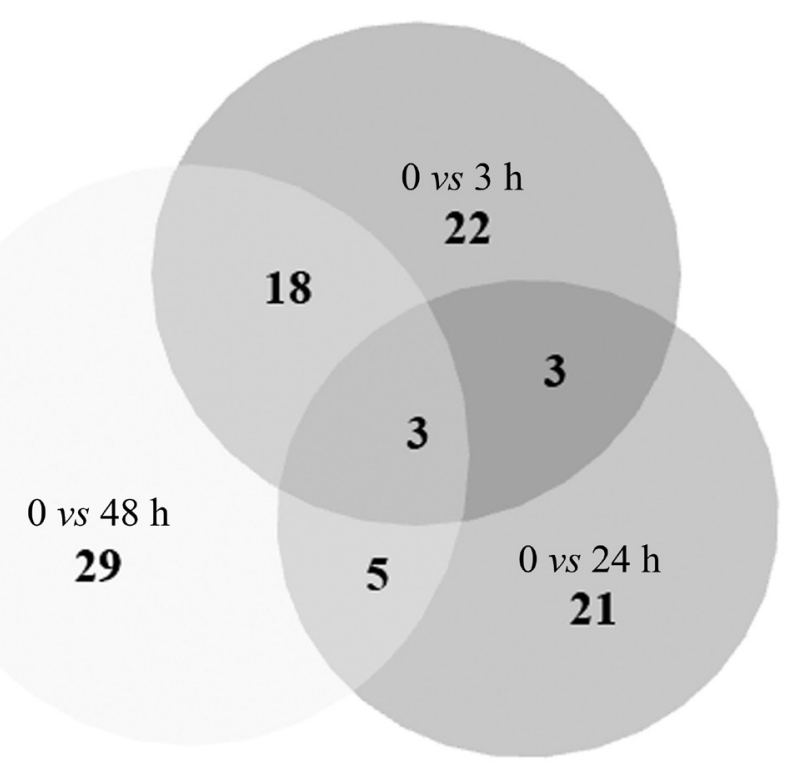

Figure 2. Venn diagram showing overlap of genes differentially expressed in $0-3 \mathrm{~h}, 0-24 \mathrm{~h}$, and $0-48 \mathrm{~h}$.

\section{Function enrichment of differentially expressed genes}

The genes selected in the three groups were submitted to perform function enrichment with DAVID software, and the screening threshold was set at $\mathrm{P}<0.05$ and FDR $<0.05$. The function clusters of $0 v s 3 \mathrm{~h}, 0 v s 24 \mathrm{~h}, 0 v s 48 \mathrm{~h}$ in each group were 2, 0 and 2, respectively. Of them, the two function clusters in 0 vs $3 \mathrm{~h}$ group and $0 v s 48 \mathrm{~h}$ group were the same (as shown in Table 2), which were related to hypoxic response or oxygen response. The enriched genes were ADM, HMOX1, VEGFA, EGLN3, APOLD1, and ANGPTL4.

Table 2. Function enrichment of differentially expressed genes.

\begin{tabular}{lllll}
\hline Category & Term & P value & Genes & FDR \\
\hline GOTERM_BP_FAT & $\begin{array}{l}\text { GO:0001666 response } \\
\text { to hypoxia }\end{array}$ & $2.58 \mathrm{E}-06$ & ADM, HMOX1, VEGFA, & E.003831 \\
GOTERM_BP_FAT & $\begin{array}{l}\text { GO:0070482 response } \\
\text { to oxygen levels }\end{array}$ & $3.31 \mathrm{E}-06$ & $\begin{array}{l}\text { ADM, HMOXD1, ANGPT4 } \\
\text { EGLG, APOLD1, ANGPTL4 }\end{array}$ \\
\hline
\end{tabular}

$\mathrm{FDR}=$ false discovery rate

\section{Researching drugs in the CMAP data}

Differentially expressed genes were partitioned into up or downregulated groups, and then enriched with significantly changed genes obtained from treatment of small molecules from the CMap database. Targeted molecules observed to induce more than $90 \%$ similar effects to hypoxia stimulus were selected (Table 3 ). If the score is close to 1 , it indicates that this small molecule can simulate the similar gene expression as exposure of pulmonary microvascular endothelial cells to hypoxia. As shown in Table 3, the pindolol, sulfapyridine, and 
ciclopirox were relevant molecules to induce genes response to hypoxia. Structures of small molecule drugs as well as drug information were then obtained from the DrugBank project (as shown in Table 4).

\begin{tabular}{|c|c|c|c|c|c|c|c|c|c|c|c|}
\hline \multicolumn{4}{|c|}{$0 v s 3 \mathrm{~h}$} & \multicolumn{4}{|c|}{$0 v s 24 \mathrm{~h}$} & \multicolumn{4}{|c|}{$0 v s 48 \mathrm{~h}$} \\
\hline CMAP name & Dose & Cell & Score & CMAP name & Dose & Cell & Score & CMAP name & Dose & Cell & Score \\
\hline Pindolol & $16 \mu \mathrm{M}$ & PC3 & 1 & Sulfapyridine & $16 \mu \mathrm{M}$ & HL60 & 0.973 & Ciclopirox & $15 \mu \mathrm{M}$ & HL60 & 1 \\
\hline Trimethobenzamide & $9 \mu \mathrm{M}$ & PC3 & 0.968 & Rotenone & $1 \mu \mathrm{M}$ & PC3 & 0.971 & Cicloheximide & $14 \mu \mathrm{M}$ & PC3 & 0.954 \\
\hline Daunorubicin & $1 \mu \mathrm{M}$ & PC3 & 0.964 & Naloxone & $11 \mu \mathrm{M}$ & MCF7 & 0.954 & Orphenadrine & $13 \mu \mathrm{M}$ & PC3 & 0.915 \\
\hline Deptropine & $8 \mu \mathrm{M}$ & PC3 & 0.924 & Felodipine & $10 \mu \mathrm{M}$ & PC3 & 0.948 & Lynestrenol & $14 \mu \mathrm{M}$ & MCF7 & 0.912 \\
\hline Canrenoic acid & $10 \mu \mathrm{M}$ & PC3 & 0.919 & Sulfadiazine & $16 \mu \mathrm{M}$ & PC3 & 0.945 & Chlorprothixene & $11 \mu \mathrm{M}$ & PC3 & 0.911 \\
\hline (-)-isoprenaline & $16 \mu \mathrm{M}$ & PC3 & 0.912 & Rescinnamine & $6 \mu \mathrm{M}$ & HL60 & 0.939 & Cefotiam & $7 \mu \mathrm{M}$ & PC3 & -0.918 \\
\hline Ikarugamycin & $2 \mu \mathrm{M}$ & MCF7 & 0.907 & 0179445-0000 & $1 \mu \mathrm{M}$ & PC3 & 0.933 & Mercaptopurine & $10 \mu \mathrm{M}$ & PC3 & -0.923 \\
\hline Lidocaine & $15 \mu \mathrm{M}$ & MCF7 & 0.906 & Cefoperazone & $6 \mu \mathrm{M}$ & MCF7 & 0.932 & Ranitidine & $11 \mu \mathrm{M}$ & PC3 & -0.926 \\
\hline Alclometasone & $8 \mu \mathrm{M}$ & PC3 & 0.903 & Cephaeline & $6 \mu \mathrm{M}$ & MCF7 & 0.931 & Ethotoin & $20 \mu \mathrm{M}$ & MCF7 & -0.931 \\
\hline Pivampicillin & $9 \mu \mathrm{M}$ & MCF7 & -0.903 & Ciclacillin & $12 \mu \mathrm{M}$ & PC3 & 0.931 & Sodium phenylbutyrate & $1 \mathrm{mM}$ & PC3 & -0.934 \\
\hline Tanespimycin & $1 \mu \mathrm{M}$ & PC3 & -0.907 & Triamterene & $16 \mu \mathrm{M}$ & PC3 & 0.929 & Rimexolone & $11 \mu \mathrm{M}$ & HL60 & -0.938 \\
\hline Dexpropranolol & $14 \mu \mathrm{M}$ & PC3 & -0.91 & Adiphenine & $11 \mu \mathrm{M}$ & PC3 & 0.923 & Amoxapine & $13 \mu \mathrm{M}$ & PC3 & -0.949 \\
\hline Abamectin & $5 \mu \mathrm{M}$ & $\mathrm{PC} 3$ & -0.922 & Nalidixic acid & $15 \mu \mathrm{M}$ & MCF7 & 0.914 & Procaine & $15 \mu \mathrm{M}$ & PC3 & -0.964 \\
\hline Benfotiamine & $9 \mu \mathrm{M}$ & MCF7 & -0.922 & Fluphenazine & $10 \mu \mathrm{M}$ & MCF7 & 0.912 & Lomefloxacin & $10 \mu \mathrm{M}$ & MCF7 & -0.976 \\
\hline Trolox C & $16 \mu \mathrm{M}$ & MCF7 & -0.934 & Mexiletine & $19 \mu \mathrm{M}$ & MCF7 & 0.902 & Midecamycin & $5 \mu \mathrm{M}$ & PC3 & -1 \\
\hline Chlorzoxazone & $24 \mu \mathrm{M}$ & PC3 & -0.953 & AG-012559 & $10 \mu \mathrm{M}$ & PC3 & -0.909 & & & & \\
\hline Estriol & $14 \mu \mathrm{M}$ & PC3 & -0.985 & Cefadroxil & $11 \mu \mathrm{M}$ & MCF7 & -1 & & & & \\
\hline
\end{tabular}

Table 4. Highest score drugs using DrugBank.

\begin{tabular}{|c|c|c|c|c|}
\hline & Accession No. & Type & Categories & Targets \\
\hline Pindolol & DB00960 (APRD00678) & Small molecule & $\begin{array}{l}\text { Antihypertensive } \\
\text { Adrenergic beta-antagonists } \\
\text { Vasodilator } \\
\text { Serotonin antagonists }\end{array}$ & $\begin{array}{l}\text { Beta-2 adrenergic receptor } \\
\text { Beta-1 adrenergic receptor } \\
\text { 5-Hydroxytryptamine 1A receptor } \\
\text { 5-Hydroxytryptamine 1B receptor }\end{array}$ \\
\hline Sulfapyridine & DB00891 (APRD00491) & Small molecule & $\begin{array}{l}\text { Anti-infective } \\
\text { Anti-infectives } \\
\text { Dermatologic } \\
\text { Sulfonamides } \\
\text { Dermatitis herpetiformis suppressant }\end{array}$ & Dihydropterate synthase \\
\hline Ciclopirox & DB01188 (APRD00871) & Small molecule & Antifungal & Trivalent metal cations \\
\hline
\end{tabular}

\section{DISCUSSION}

Chronic hypoxia is well known to cause hypertension and vascular remodeling in the pulmonary vasculature in various animal models of human pathophysiology (Zhao, 2010). Whatever the initial cause, pulmonary arterial hypertension involves the vasoconstriction or tightening of blood vessels connected to and within the lungs (Wang et al., 2011). Previous studies have indicated that vascular endothelial cells, equipped with oxygen sensors, can perceive an imbalance in oxygen levels and initiate a vessel normalization programme via HIF1 $\alpha$ to re-establish oxygen delivery (Carmeliet and Jain, 2011). In this study, we screened several differentially expressed genes after exposure of pulmonary microvascular endothelial cells to hypoxia for 3, 24, $48 \mathrm{~h}$ compared with normoxia. Among them, six genes (ADM, HMOX1, VEGFA, EGLN3, APOLD1, and ANGPTL4) were predicted to play important roles in response to the hypoxia state. Adrenomedullin (ADM) is a regulatory peptide with structural ho- 
mology to calcitonin gene-related peptide and amylin (Muff et al., 1995). ADM is upregulated by HIF $1 \alpha$ and functions as a survival factor against hypoxia/reoxygenation-induced cell death by suppression of reactive oxygen species via thiol redox systems (Kim et al., 2010). Heme oxygenase 1 (HMOX1) is an inducible enzyme that catalyzes the rate-limiting step in the conversion of free heme into carbon monoxide, free iron, and biliverdin, which is subsequently catabolized into bilirubin by biliverdin reductase (Hill-Kapturczak et al., 2002). In addition to its primary role in heme degradation, HMOX1 has been also recognized to play important roles in resolution of lung hypoxia and inflammation (Christou et al., 2000). However, in this study, we found HMOX1 was downregulated. The repression of HMOX1 expression may represent the adaptation to hypoxia in certain cell types (Nakayama et al., 2000). VEGF is a signal protein produced by cells that stimulates vasculogenesis and angiogenesis. It is part of the system that restores the oxygen supply to tissues when blood circulation is inadequate (Holmes et al., 2007). Hypoxia can upregulate VEGF expression in alveolar epithelial cells in vitro and in vivo (Pham et al., 2002). Egl nine homolog 3 (C. elegans) (EGLN3) is a member of mammalian $E G L N$ family, encoding prolyl hydroxylase isoforms (PHD) that mediate a feedback mechanism for down-regulating HIF-1 $\alpha$ expression (Lieb et al., 2002). PHD3 mRNA and protein are markedly upregulated after $3 \mathrm{~d}$ of hypoxia (Chen et al., 2006). EGLN3 may be involved in the low hematocrit phenotype exhibited by the Tibetan population, and hence, EGLN3 may play a role in the heritable adaptation of this population to life at high altitude (Simonson et al., 2010). Apolipoprotein L domain containing 1 (APOLD1) is a new endothelial cell early response protein that may play a role in regulation of endothelial cell signaling and vascular function (Regard et al., 2004). APOLD1 is also found to be upregulated by hypoxia (Copple et al., 2011). Angiopoietin-like 4 (ANGPTL4) gene is induced under hypoxic (low oxygen) conditions in endothelial cells and is the target of peroxisome proliferation activators, which also act as an apoptosis survival factor for vascular endothelial cells (Kim et al., 2000).

In this study, we also found that several drugs, including pindolol, sulfapyridine, and ciclopirox could induce similar genes response to hypoxia. Pindolol is a nonselective beta blocker with partial beta-adrenergic receptor agonist activity, which means that pindolol, particularly in high doses, exerts effects like epinephrine or isoprenaline, albeit limited. Pindolol also shows membrane stabilizing effects like quinidine, possibly accounting for its antiarrhythmic effects (Isaac, 2004). Pindolol markedly inhibits the development of hypoxic pulmonary vasoconstriction (Takashio et al., 1992). Sulfapyridine, a constituent of sulfasalazine, has been demonstrated to have anti-inflammatory role and can inhibit the production of IL-8/CXCL8 by pro-inflammatory cytokine-stimulated endothelial cells (Volin et al., 1999). Ciclopirox olamine is a synthetic antifungal agent for topical dermatologic treatment of superficial mycoses. It is most useful against tinea versicolor (Niewerth et al., 2003). Antimycotic ciclopirox olamine also acts as a bidentate iron chelator capable of stabilizing HIF- $1 \alpha$ and then activating endogenous HIF-1 target genes, including VEGF to promote angiogenesis remodeling (Linden et al., 2003).

In summary, we demonstrate that hypoxia can induce some differentially expressed genes upregulated or downregulated (ADM, HMOX1, VEGFA, EGLN3, APOLD1, and ANGPTL4) which are closely related to hypoxia response in pulmonary microvascular endothelial cells. Three drugs, namely pindolol, sulfapyridine, ciclopirox, that provide new clues and basis for treating hypoxia-related pulmonary diseases. However, these findings need specific genetic experiments for verification. 


\section{ACKNOWLEDGMENTS}

Research supported by the scientific research program of Shanghai's Health Bureau under grant \#2009Y071 and \#2010108, and also supported by the Key Program of Shanghai Science and Technology Committee under grant \#11411951400.

\section{Conflicts of interest}

The authors have no conflict of interest to declare. The data have not been published and are not under consideration elsewhere, and all authors have approved the submission of the manuscript.

\section{REFERENCES}

Barst RJ, McGoon M, Torbicki A, Sitbon O, et al. (2004). Diagnosis and differential assessment of pulmonary arterial hypertension. J. Am. Coll. Cardiol. 43: 40S-47S.

Beghetti M, Berger R, Schulze-Neick I, Barst R, et al (2011). Tracking outcomes and practice in pediatric pulmonary hypertension.

Benjamini Y and Hochberg Y (1995). Controlling the false discovery rate: a practical and powerful approach to multiple testing. J. Roy. Statist. Soc. Series B 57: 289-300.

Carmeliet P and Jain RK (2011). Principles and mechanisms of vessel normalization for cancer and other angiogenic diseases. Nat. Rev. Drug Discov. 10: 417-427.

Chen BP, Li YS, Zhao Y, Chen KD, et al. (2001). DNA microarray analysis of gene expression in endothelial cells in response to 24-h shear stress. Physiol. Genomics 7: 55-63.

Chen YR, Dai AG, Hu RC and Jiang YL (2006). Differential and reciprocal regulation between hypoxia-inducible factor- $\alpha$ subunits and their prolyl hydroxylases in pulmonary arteries of rat with hypoxia-induced hypertension. Acta Biochim. Biophys. Sin. 38: 423-434.

Christou H, Morita T, Hsieh CM, Koike H, et al. (2000). Prevention of hypoxia-induced pulmonary hypertension by enhancement of endogenous heme oxygenase-1 in the rat. Circ. Res. 86: 1224-1229.

Clerici C and Planès C (2009). Gene regulation in the adaptive process to hypoxia in lung epithelial cells. Am. J. Physiol. Lung. Cell. Mol. Physiol. 296: L267-L274.

Copple BL, Bai S, Burgoon LD and Moon JO (2011). Hypoxia-inducible factor-1alpha regulates the expression of genes in hypoxic hepatic stellate cells important for collagen deposition and angiogenesis. Liver Int. 31: 230-244.

Fujita A, Sato JR, Rodrigues LO, Ferreira CE, et al. (2006). Evaluating different methods of microarray data normalization. BMC Bioinformatics 7: 469.

Gentleman R (2005). Bioinformatics and Computational Biology Solutions Using R and Bioconductor. Springer Verlag.

Hill-Kapturczak N, Chang SH and Agarwal A (2002). Heme oxygenase and the kidney. DNA Cell Biol. 21: 307-321.

Holmes K, Roberts OL, Thomas AM and Cross MJ (2007). Vascular endothelial growth factor receptor-2: structure, function, intracellular signalling and therapeutic inhibition. Cell Signal. 19: 2003-2012.

Huang da W, Sherman BT and Lempicki RA (2009). Systematic and integrative analysis of large gene lists using DAVID bioinformatics resources. Nat. Protoc. 4: 44-57.

Isaac MT (2004). Review: combining pindolol with an SSRI improves early outcomes in people with depression. Evid. Based Ment. Health 7: 107.

Kim I, Kim HG, Kim H, Kim HH, et al. (2000). Hepatic expression, synthesis and secretion of a novel fibrinogen/ angiopoietin-related protein that prevents endothelial-cell apoptosis. Biochem. J. 346: 603-610.

Kim SM, Kim JY, Lee S and Park JH (2010). Adrenomedullin protects against hypoxia/reoxygenation-induced cell death by suppression of reactive oxygen species via thiol redox systems. FEBS Lett. 584: 213-218.

Lamb J, Crawford ED, Peck D, Modell JW, et al. (2006). The Connectivity Map: using gene-expression signatures to connect small molecules, genes, and disease. Science 313: 1929-1935.

Lieb ME, Menzies K, Moschella MC, Ni R, et al. (2002). Mammalian EGLN genes have distinct patterns of mRNA expression and regulation. Biochem. Cell Biol. 80: 421-426.

Linden T, Katschinski DM, Eckhardt K, Scheid A, et al. (2003). The antimycotic ciclopirox olamine induces HIF-1 $\alpha$ 
stability, VEGF expression, and angiogenesis. FASEB J. 17: 761-763.

Minamino T, Christou H, Hsieh CM, Liu Y, et al. (2001). Targeted expression of heme oxygenase-1 prevents the pulmonary inflammatory and vascular responses to hypoxia. Proc. Natl. Acad. Sci. U. S. A. 98: 8798-8803.

Muff R, Born W and Fischer JA (1995). Calcitonin, calcitonin gene-related peptide, adrenomedullin and amylin: homologous peptides, separate receptors and overlapping biological actions. Eur. J. Endocrinol. 133: 17-20.

Nakayama M, Takahashi K, Kitamuro T, Yasumoto K, et al. (2000). Repression of heme oxygenase-1 by hypoxia in vascular endothelial cells. Biochem. Biophys. Res. Commun. 271: 665-671.

Niewerth M, Kunze D, Seibold M, Schaller M, et al. (2003). Ciclopirox olamine treatment affects the expression pattern of Candida albicans genes encoding virulence factors, iron metabolism proteins, and drug resistance factors. Antimicrob. Agents Chemother. 47: 1805-1817.

Pham I, Uchida T, Planes C, Ware LB, et al. (2002). Hypoxia upregulates VEGF expression in alveolar epithelial cells in vitro and in vivo. Am. J. Physiol. Lung Cell. Mol. Physiol. 283: L1133-L1142.

Regard JB, Scheek S, Borbiev T, Lanahan AA, et al. (2004). Verge: a novel vascular early response gene. J. Neurosci. 24: 4092-4103.

Shimoda LA and Semenza GL (2011). HIF and the lung: role of hypoxia-inducible factors in pulmonary development and disease. Am. J. Respir. Crit. Care Med. 183: 152-156.

Simonson TS, Yang Y, Huff CD, Yun H, et al. (2010). Genetic evidence for high-altitude adaptation in Tibet. Science 329: $72-75$.

$\mathrm{Su} \mathrm{H}, \mathrm{Hu} \mathrm{N}$, Yang HH, Wang C, et al. (2011). Global gene expression profiling and validation in esophageal squamous cell carcinoma and its association with clinical phenotypes. Clin. Cancer Res. 17: 2955-2966.

Takashio T, Yamashita H and Onodera S (1992). Inhibitory effect of pindolol on hypoxic pulmonary vasoconstriction. Am. J. Physiol. 262: H130-H135.

Troyanskaya O, Cantor M, Sherlock G, Brown P, et al. (2001). Missing value estimation methods for DNA microarrays. Bioinformatics 17: 520-525.

Truog WE, Xu D, Ekekezie II, Mabry S, et al. (2008). Chronic hypoxia and rat lung development: analysis by morphometry and directed microarray. Pediatr. Res. 64: 56-62.

Tuder RM, Davis LA and Graham BB (2012). Targeting energetic metabolism: a new frontier in the pathogenesis and treatment of pulmonary hypertension. Am. J. Respir. Crit. Care Med. 185: 260-266.

Volin MV, Harlow LA, Woods JM, Campbell PL, et al. (1999). Treatment with sulfasalazine or sulfapyridine, but not 5-aminosalicyclic acid, inhibits basic fibroblast growth factor-induced endothelial cell chemotaxis. Arthritis Rheum. 42: 1927-1935.

Wang J, Zhang D, Remillard CV and Yuan JXJ (2011). Pathogenic Roles of $\mathrm{Ca}^{2+}$ and Ion Channels in Hypoxia-Mediated Pulmonary Hypertension. Textbook of Pulmonary Vascular Disease, 683-694.

Zhao L (2010). Chronic hypoxia-induced pulmonary hypertension in rat: the best animal model for studying pulmonary vasoconstriction and vascular medial hypertrophy. Drug Discov. Today Dis. Model. 7: 83-88.

Zhou B, Fan FD, Xu W, Larsson O, et al. (2011). Genome-wide analysis of translationally regulated genes in hypoxic alveolar epithelial cells. Proc. Am. Thorac. Soc. 8: 207.

Zhou G, Dada LA and Sznajder JI (2008). Regulation of alveolar epithelial function by hypoxia. Eur. Respir. J. 31: 11071113. 